\title{
Applied Research of Krashen's Language Monitoring Model Theory in College English Listening Teaching

\author{
Dongmei Sheng
}

School of Foreign Languages Jilin Business and Technology College Changchun Jilin China

Email: 455635403@qq.com

\section{Keywords: Krashen; Language monitoring; English Listening Teaching; Input}

\begin{abstract}
The aim of this study is to search for the best teaching method to improve the college students' listening ability. This paper presents an analysis of the theory of Krashen's language monitoring model theory. This theory shows that inputting plays an important role in the process of listening. This paper also analyzes the influence factors of inputting and shows the strategy of improving listening ability in college English. The result suggests that the better teaching method is of great significance in improving college students' listening ability.
\end{abstract}

\section{Introduction}

As people pay more and more attention to the study of second language acquisition, and more and more theories about the second language acquisition have been discussed. Language monitoring model theory is one of the most influential theories proposed by Krashen. The Krashen's monitor model theory can mobilize the enthusiasm of students to improve the quality of input in the classroom, reduce anxiety and enable students to appreciate their listening and comprehensive communicative competence in communication, so as to stimulate student's interest in learning Chinese. Therefore, the Krashen's monitor model theory will have an important role in the reform of traditional teaching ideas and teaching methods, will promote the further development of listening teaching.

\section{Theory Background}

At the end of 1970s, the famous American linguist Krashen put forward the famous second language acquisition theory that is supervision mode in the second language acquisition principle and practice in Monitor Model. The monitor model theory mainly includes five studies on second language acquisition hypothesis, namely the acquisition and learning hypothesis, the natural order hypothesis, Monitor hypothesis, the input hypothesis, affective filter hypothesis. The second language learners have two kinds of methods. Krashen (1982) believes that the acquisition of a second language is similar to the way we master our mother tongue. The acquisition of language is a subconscious process in which language learners do not usually realize that they are learning the language, but merely that they are using the language to communicate and communicate. Therefore, the ability to master the use of language is also unconscious. On the other hand, learning language is a conscious process of learning a language. In the process of learning the language, learners pay attention to language forms and grammatical rules. So learning language is the result of know language forms and rules (Krashen, the 1984: 35). Krashen believes that the acquisition is an important process of language learning, only through learning, language can learners master the language of natural and smooth communication, and learning knowledge cannot be internalized into language acquisition system. In the natural order hypothesis, Krashen believes that learners have a predetermined order of language rules. That is to say, for language learners, what time can grasp grammatical structure or rules is determined and the learning sequence is affected by neither association nor interference.

\section{Implications of Krashen's Hypothesis for College Listening Teaching}

At present, there is a lack of necessary real situation in College English Teaching for non- English 
majors. This has weakened the promotion of College Students' listening and speaking ability in the allocation of teaching resources. Therefore, College English teachers and educational administrators should work hard at the allocation of English teaching resources, and should also make articles in the form of classroom teaching. The author suggests that English listening and speaking training can be placed in the course of students' specialized training courses, which will be taken as a form of good interaction. It gradually trains students' ability to find and solve problems. This type of teacher-student participation in classroom changes the teaching of English as in the past teacher centered lacks inspiration and interaction. In the course of teaching, students can be divided into different groups according to the basis of the students. The group discussions are discussed in the course of the class, and the divergent thinking should be inspired in the process of learning. In the course of the study process, students gradually master the autonomous and inquiry learning methods.

Effective Inputting can improve students' reading interest by setting up a reading database which meets the requirements of English syllabus. By encouraging students to use English reading databases, students can expand their reading in class, gradually master the methods and skills of reading, and deeply understand the cultural background knowledge of related articles. In the correct guidance of the teacher's teaching, it gradually cultivates students' enthusiasm and initiative in English reading, to guide students to develop their own reading plans, training students to discover and solve problems discussed below .Empirical optimization in the training of listening and speaking in the classroom teach the teachers in the establishment of empirical discussion. Listening diversifies English teaching. The application of multimedia network technology should be selected according to the current college students' interest in content. As mentioned above, traveling across the United States can help students learn about American customs and conduct their listening training. However, the original English film does not have Chinese subtitles, so it will increase the difficulty of students' understanding in the early period of listening training. Therefore, teachers can take the form of staged play to explain language and listen to it one by one. Specifically, a full situational dialogue is used as a unit to stimulate the students to understand the outline of the dialogue by repeating the play and the teacher's hints on the key words. Finally, the whole film will be broadcast continuously to establish the complete listening training for the students. At the same time, you can also choose to play English movies and you should consider the students' interests and understanding in the choice of films. On the training of English listening interest as a result of college students, you need to take the above mentioned: M T V English playing songs, and English movies; you can also play through college students' written and directed English situational stories, to lead their interest. Students can improve their English listening level in the dialogue interaction; at the same time, the shooting and playback equipment go through the above based on Krashen's theory of optimization measures, in the current college English teaching. This class organic combination of teaching methods can break through the classroom and textbooks limitations, to help students set up the concept of lifelong learning, so as to better cultivate the practical talents with higher English proficiency in the needs of society and enterprises.

The monitoring time is divided into Krashen in advance, immediate and delayed in three cases, in the teaching of listening class, teachers and students should grasp the opportunity of monitoring, rational use of monitoring techniques in the necessary time, so that the students can reasonably monitor to hear the content in the listening process. In English listening class, listening to play before the best teacher can advance to remind students to make mistakes and the key is to make the correct tips and guidance. This makes the students to monitor the hearing in advance. Immediate monitoring can also be made while the hearing is in progress. At this point, teachers should let students play their own role in monitoring language, and some of them are difficult to detect and will not affect communication.

After the completion of the monitoring activities of delay correction, the enthusiasm of this method will not hit the students when learning and teachers can give students pointed out the cause of the error and let students do the corresponding exercises. In a word, teachers should master the opportunity of monitoring so as to help student's correct mistakes and arouse their enthusiasm for 
study. Monitoring as an important link in teaching English as a foreign language, no matter when play a monitoring role. The last that monitor should be reasonable to play with caution. Therefore, monitoring should be effective, that is not time-consuming and laborious. The teacher should pay attention to emotional factors and individual factors of students. It is best to let the students play the role of self-monitoring and pay attention to students' self-learning ability. In addition to listening classes, we should also do a good job of pre and after class conscious training and study, so as to achieve the best listening effect.

Therefore, Krashen stresses that teachers should adjust their teaching methods so as to adapt themselves to the students as much as possible. In the listening class, teachers should try their best to use the words they learn and communicate with students, so that students can gain more confidence in listening. Teachers in the choice of listening materials, should consider the teaching content of the degree of difficulty, speed, also consider hearing interesting content, ensure that the listening material meets the age and psychological characteristics of students. The students' emotional anxiety is reduced and the lively classroom atmosphere is easy to form. This will help to carry out the teaching of listening.

\section{Combination of Language Input and Language Output}

Interviews and survey results show that the appropriate language output is very helpful for language learning. Students are required to output the current level of language learning, which is not only the content of the content of the input, but also which is inhaled into the digestion and absorption of learners. Learners can find themselves on the existing input master that is not thorough, so as to improve learning methods or enhance learning strength. Therefore, language teachers should combine output and input effectively to achieve the best learning effect. As for senior level students, teachers can ask students in listening to the dialogue, the story after listening according to the content of the act, material mentioned in the listening or the answers to problems or solutions. The setting of output exercises should pay special attention to the difficulty, so as not to arouse students' emotional anxiety. Therefore, it is better to carry out the output after the students have enough input. However, the input and output must be closely integrated. Without any link, it is impossible for learners to achieve the level of the target language. Only when the input language material is internalized into comprehensible output can the acquisition occur within a certain range. In order to make the input language materials into comprehensible output, we must try to create a suitable one for learners' output language environment, changing the traditional language teaching mode, providing interactive classroom teaching mode and teaching atmosphere.

\section{Conclusion}

Krashen's theory of acquisition, input, monitoring and reduction of affective filter, which is emphasized in his second language acquisition theory, is very enlightening for English listening teaching. This requires us English teachers pay attention to training the students' ability to understand the language in teaching, especially the listening ability, listening as much as possible to create a rich language environment for students. Only in this way, can students keep confident attitude in learning English listening class, and gradually improve the comprehensive ability of using language, improve communication skills, which grew into a solid foundation of qualified personnel. In summary, the monitor model theory not only can help the listening teaching practice a, but also plays a practical role in guiding and promoting for listening teaching. Teachers should make full use of all teaching resources and means to improve students' listening ability in a more favorable language environment and then optimize the students' English acquisition.

\section{Acknowledgements}

This paper is one of research findings from the project “Applied Research of Krashen's language Monitoring Model Theory in College English Listening Teaching" which is general subject of teaching research of higher education in Jilin province in 2015 


\section{References}

[1] Adams, R. J. (2004). Learner-learner interactions: Implications for second language acquisition (Doctoral dissertation). Available from Pro Quest Dissertations and Theses database. (UMI No: 3148617)

[2] Anthony, A. R. (2008). Output strategies for English-language learners: Theory to practice. The Reading Teacher 61 (6), 472-482.

[3] Baleghizadeh, S.,\&Borzabadi, D. (2007). The impact of two types of input modification on EFL reading comprehension: Linguistic Language and Literature--Society of Iran, 1 (3),vs. Interactional. Teaching 71--94.

[4] Brewer, B. (2008). Effects of lexical slim canon and elaboration on readers 'local- level perceived comprehension (Master's thesis). Available from Proust Dissertations and Theses database

[5] Cho, M. Y (2010). The effects of input enhancement and written recall on noticing and acquisition. Innovation in Language Learning and Teaching, 4 (1), 7-87. Doi:10.1080/ 17501220903388900

[6] Combs, C. H. (2009). What cognitive processes are triggered by input enhancement? Working papers in TESOL \& Applied Linguistics (Special issue J, 4. Retrieved from http: //journals. Tic-library. Org/index. Pop/tool/article/viewed Interstitial/68/74

[7] De Santos, P. L. (2007). Text enhancement and the acquisition of English verbal

morphology 妙 LI Haitian Creole speakers. Available from Proust Dissertations and Theses database. (UMI No. 9315947)

[8] [Gas, S. (2008). Second language acquisition: An introductory course. London, U.K.:Rutledge.

[9] Hanaoka, O. (2007). Output, noticing, and learning: An investigation into the role of spontaneous attention to form in a four-stage writing task. Language Teaching Research, 11 (4), 459-479. Doe: $10.1177 / 1362168807080963$

[10] Kaivanpanah,S.,\&Alavi, M. (2008). Deriving unknown word meaning from context: Is it reliable? RELC Journal, 39 (1), 77-95. doi: 10.1177/0033688208091141 